\title{
ШЛЯХИ ПОКРАЩЕННЯ ЕФЕКТИВНОСТІ ФУНКЦІОНУВАННЯ АДМІНІСТРАТИВНО-ПРАВОВОГО ЗАБЕЗПЕЧЕННЯ ПРАВА НА МИРНІ ЗІБРАННЯ В УКРАЇН
}

\author{
WAYS TO IMPROVE THE EFFICIENCY OF THE FUNCTIONING OF \\ THE ADMINISTRATIVE AND LEGAL ENFORCEMENT OF THE RIGHT \\ ON PEACEFUL ASSEMBLY IN UKRAINE
}

\author{
Кобрусєва $€$. А. \\ доктор юридичних наук, доцент, \\ доцент кафедри адміністративного і кримінального права \\ Дніпровський національний університет імені Олеся Гончара
}

Kobrusieva Ye.

Doctor of Science in Law, Associate Professor of Administrative and Criminal Law, Oles Honchar Dnipro National University

\begin{abstract}
Наукова стаття присвячена дослідженню змісту правового забезпечення конституційного права на мирні зібрання в Україні, як засобу забезпечення дотримання прав громадян. Забезпечення права на мирні зібрання в Україні, в двигуні Європейських перегонів великої політики, породжує високу активність волевиявлення та захисту прав та свобод громадян. 3 урахуванням процесів становлення держави та тривалого реформування різних державних інституцій, свобода та право громадян на мирні зібрання, ставить перед органами влади питання відповідності активності громадян у вирішенні своєї участі на державному та регіональному рівнях, відстоювання своїх інтересів шляхом вираження та донесення поглядів та незгоди до державних та місцевих структур влади. Постає питання законодавчого та практичного регулювання такого болючого питання як відносини влади та суспільства шляхом урегулювання проведення мирних зібрань та активних «без зброї» акцій впливу на державні установи різного рівня. 3 урахуванням міжнародного досвіду, пропонуються алгоритми та механізми забезпечення права на мирні зібрання, які своєю складовою становлять можливість контролю спеціалізованих уповноважених органів за реалізацією права громадян на мирні зібрання та звернення до Європейського суду 3 прав людини у разі порушених прав та свобод громадян. Оскільки впровадження європейських стандартів є однією з передумов інтеграції України в європейський правовий простір. Оскільки право на свободу мирних зібрань не може бути реалізованим за відсутності кореспондуючих обов'язків, покладених на державу в особі їі уповноважених органів, аналіз норм Конституції та законів України, дозволив виокремити такі органи у категорію суб’єктів владних повноважень забезпечення права на мирні зібрання. Ключові слова: мирні зібрання, акції впливу, порушення права на мирні зібрання, суб'єкти забезпечення права на мирні зібрання, державні органи.
\end{abstract}

Научная статья посвящена исследованию содержания правового обеспечения конституционного права на мирные собрания в Украине как средства обеспечения соблюдения прав граждан. Обеспечение права на мирные собрания в Украине, в двигателе Европейской гонки большой политики, порождает высокую активность волеизъявления и защиты прав и свобод граждан. С учетом процессов становления государства и длительного реформирования различных государственных институций, свобода и право граждан на мирные собрания, ставит перед органами власти вопросы соответствия активности граждан в решении своего участия на государственном и региональном уровнях, отстаивания своих интересов путем выражения и донесения взглядов и несогласия до государственных и местные власти. Возникает вопрос законодательного и практического регулирования такого болезненного вопроса как отношения власти и общества путем урегулирования проведения мирных собраний и активных «без оружия» акций влияния на государственные учреждения разного уровня. С учетом международного опыта, предлагаются алгоритмы и механизмы обеспечения права на мирные собрания, которые своей составляющей составляют возможность контроля специализированных уполномоченных органов за реализацией права граждан на мирные собрания и обращение в Европейский суд по правам человека в случае нарушенных прав и свобод граждан. Поскольку внедрение европейских стандартов является одной из предпосылок интеграции Украины в европейское правовое пространство. Поскольку право на свободу мирных собраний не может быть реализовано при отсутствии корреспондирующих обязанностей, возложенных на государство в лице его уполномоченных органов, анализ норм Конституции и законов Украины, позволил выделить такие органы в категорию субъектов властных полномочий обеспечения права на мирные собрания. 
Ключевые слова: мирные собрания, акции влияния, нарушение права на мирные собрания, субъекты обеспечения права на мирные собрания, государственные органы.

The scientific article is devoted research of maintenance of the legal providing of constitutional right of peaceful assemblies in Ukraine, as to the backer-up observance of rights for citizens. Ensuring the right to peaceful assembly in Ukraine, in the engine of the European race for big politics, generates high activity of expression of will and protection of the rights and freedoms of citizens. Taking into account the processes of state formation and long-term reform of various state institutions, the freedom and right of citizens to peaceful assembly raises before the authorities the question of compliance of citizens' activity in deciding their participation at the state and regional levels, defending their interests by expressing views and disagreements. and local authorities. There is a question of legislative and practical regulation of such a painful issue as the relationship between government and society by regulating the holding of peaceful assemblies and active "unarmed" actions of influence on government agencies at various levels. Taking into account international experience, algorithms and mechanisms for ensuring the right to peaceful assembly are proposed, which include the possibility of control of specialized authorized bodies over the exercise of citizens' right to peaceful assembly and appeal to the European Court of Human Rights in case of violated rights and freedoms. Because the implementation of European standards is one of the prerequisites for Ukraine's integration into the European legal space. Since the right to freedom of peaceful assembly cannot be exercised in the absence of corresponding responsibilities imposed on the state by its authorized bodies, the analysis of the Constitution and laws of Ukraine allowed to separate such bodies into the category of subjects of power to ensure the right to peaceful assembly. Key words: peaceful assemblies, actions of influence, violation of the right to peaceful assembly, subjects of ensuring the right to peaceful assembly, state bodies.

Постановка проблеми. Проблематика захисту права на мирні зібрання та практика судових справ з цього напрямку $є$ надзвичайно актуальною.

Дотримання свободи зібрань набула в Україні особливої актуальності через численні акції протесту, які вже неодноразово відбувалися в Україні. Дотепер правове забезпечення права на мирні зібрання продовжує розвиватися неоднорідно і нерідко залежить від соціально-політичної ситуації в країні.

Ситуація 3 адміністративно-правовим забезпеченням права на мирні зібрання характеризується рядом складнощів та недоліків. Так, слід зазначити, що незважаючи на встановлені державні гарантії права на вільне проведення публічних заходів, під час реалізації цього права виникають серйозні труднощі, пов'язані як з питаннями забезпечення громадського порядку при проведенні мирних зібрань, так і проблемами політичного характеру, які, подекуди, зводяться до небажання влади сприймати певні думки суспільства і реагувати на них[1].

Практика останніх років показує, що органи державної влади та місцевого самоврядування часто зловживають можливостями щодо недопущення проведення масових акцій протесту. Ситуацією взаємного нерозуміння влади і населення користуються радикально налаштовані угруповання, переводячи виниклі конфлікти, як правило, економічного характеру в політичну площину [2].

Аналіз останніх досліджень і публікацій. Проблема дотримання прав і свобод громадян в Україні особливої актуальності набули через численні акції протесту, які відбуваються як правило із політичних мотивів, в умовах зміни політичних режимів в Україні, а разом з тим і з інших мотивів реалізації права на мирні зібрання, які відбуваються в Україні. Таким чином, хочемо зазначити, що в умовах сьогодення, де право громадянина захищається міжнародними нормами, питання права громадян на мирні зібрання привертає увагу науковців, серед яких: М.О. Баймуратов, В.В. Букач, О.В. Васьковська, Т.І. Гудзь, М.М. Денісова, О.С. Денісова, О.Ю. Дрозд, В.В. Заросило, О.В. Колісник, А.Т. Комзюк, Р.О. Куйбіда, М.І. Логвиненко, С.М. Міщенко, О.Б. Онишко, В.Д. Остапенко, В.Г. Поліщук, Е.

Формулювання цілей статті (постановка завдання). Наукова стаття присвячена дослідженню змісту правового забезпечення конституційного права на мирні зібрання в Україні, як засобу забезпечення дотримання прав громадян. Забезпечення права на мирні зібрання в Україні, в двигуні Європейських перегонів великої політики, породжує високу активність волевиявлення та захисту прав та свобод громадян.

Виклад основного матеріалу дослідження. Українським законодавством передбачається повідомний порядок проведення мирних зібрань. Однак таким його можна вважати 3 великою часткою умовності, оскільки в даному випадку передбачається узгодження з владою можливості проведення публічного заходу.

Щодо напрямів удосконалення відповідальності за порушення правових норм в сфері забезпечення права на мирні зібрання, то варто зазначити, що суб'єкти владних повноважень повинні виконувати свої юридичні зобов'язання і нести юридичну відповідальність за невиконання норм права. В даному випадку не має суттєвої різниці - процедурне або матеріальне, а також незалежно від того, чи мало місце таке правопорушення до, під час або після проведення мирного зібрання [3]. Персональна відповідальність повинна оцінюватися згідно з відповідними принципами адміністративного або криміналь- 
ного права. Коли мова йде про застосування надмірної сили, залежно від ступеня тяжкості злочину можуть застосовуватися різні форми відповідальності. Надмірне застосування сили може також підпадати під визначення «жорстоке поводження» за змістом ст. 3 Європейської конвенції з прав людини [4].

Важливою діяльністю, яка потребує правового удосконалення, є моніторинг та оцінка поведінки суб'єктів владних повноважень під час і після мирного зібрання[5]. Питання дотримання співробітниками правоохоронних органів міжнародних стандартів у сфрері прав людини повинно ретельно контролюватися і оцінюватися після цієї події. Позитивною практикою стосовно діяльності незалежного наглядового органу $є$ розгляд та подання доповідей про будь-яку велику поліцейську операцію, пов'язану з публічними зборами. Розроблений механізм подання скарг повинен бути адекватним, оперативним, таким, що підлягає громадському контролю (відкритим та прозорим), а також забезпечувати можливість участі заявника у цьому процесі.

Вважаємо за доцільне навести приклад Північної Ірландії, де експерти з прав людини з поліцейського наглядового органу (поліцейської ради) регулярно контролюють всі етапи поліцейських операцій, пов'язаних з суперечливими зборами. Позитивною практикою для такого органу $є$ також публікація статистичних даних про кількість отриманих скарг, їх характер та наслідки з метою забезпечення прозорості. Очікування того, що проти співробітника поліції, щодо якого $€$ докази його неправомірної поведінки, буде порушено кримінальне або дисциплінарне провадження, $€$ важливим захистом від безкарності і необхідною умовою довіри громадськості до системи подачі скарг на дії поліції. Прокуратура, поліція та незалежний орган з розгляду скарг на дії поліції повинні обґрунтовувати свої рішення, що стосуються кримінального та дисциплінарного провадження, за яке вони несуть відповідальність.

Потребує належного законодавчого закріплення обов'язок проводити ефективне розслідування випадків зловживання владою, включаючи випадки насильства, і надавати жертвам ефективні засоби правового захисту. Будь-яке зловживання службовими повноваженнями та порушення закону посадовими особами державних органів або органів місцевого самоврядування, включаючи випадки незаконного розгону або дострокового припинення мирного зібрання, має призвести до оперативного та незалежного розслідування. Дане твердження в рівній мірі відноситься до актів насильства, загроз насильства або підбурювання до ненависті щодо учасників зборів з боку інших учасників, співробітників пра- воохоронних органів або третіх осіб.

Винні мають бути притягнуті до юридичної відповідальності належним чином, а жертви повинні бути проінформовані про можливі засоби правового захисту. При розслідуванні таких справ органи державної влади повинні, як постановив Європейський суд з прав людини, «робити все розумне в даних обставинах для збору і забезпечення доказів, досліджувати всі практичні засоби встановлення істини і виносити повністю обґрунтовані, неупереджені і об'єктивні рішення, не залишаючи поза увагою підозрілих фактів, які можуть свідчити про насильство, викликане, наприклад, расовою або релігійною нетерпимістю, або насильство, мотивоване дискримінацією за ознакою статі»[6]. У випадках, коли є твердження про надмірне або інше незаконне застосування сили співробітниками правоохоронних органів, контролюючий суб'єкт повинен проводити ефективні розслідування таких дій таким чином, щоб забезпечити підзвітність відповідних співробітників поліції.

Іншим важливим напрямом удосконалення адміністративно-правового забезпечення права на мирні зібрання є широке застосування європейських стандартів та необхідність проведення розслідувань. Як зазначає Європейський суд з прав людини, - при прийнятті рішення про те, чи була дія або реакція держави розумними і пропорційними, необхідно провести об'єктивну і оперативну оцінку всієї сукупності обставин. У недавньому прецедентному праві ЄСПЛ зобов'язав держави розробити чіткі зводи правил, що стосуються здійснення директив стосовно застосування сили, включаючи сльозогінний газ, а також систему, що гарантує адекватну підготовку співробітників правоохоронних органів, а також достатній контроль і нагляд за співробітниками під час проведення мирного зібрання. Крім того, ЄСПЛ зажадав від держав провести ефективний «еx post facto» огляд необхідності, пропорційності і розумності будь-якого застосування сили, особливо проти людей, які не чинять насильницького опору[7].

Особлива увага в рамках міжнародно-правового регулювання приділяється відповідальності за порушення права на життя. Так, право на життя, передбачене ст. 6 Міжнародного пакту про громадянські і політичні права та ст. 2 Конвенції про захист прав людини і основоположних свобод, охоплює не тільки випадки умисного вбивства, а й випадки, коли застосування сили ненавмисно призводить до позбавлення життя. Захист цього права передбачає, зокрема, сувору та об'єктивну перевірку необхідності застосування сили правоохоронними органами. Інакше кажучи, органу державної влади необхідно переконливо довести, що застосування сили було 
необхідним в даних обставинах, а не надмірним, що означає, що інші, менш агресивні заходи не досягли б передбачуваного ефекту[9, 10]. Згідно постанови Європейського суду з прав людини, «... не може бути такої необхідності, якщо відомо, що особа, яка підлягає арешту, не становить загрози для життя і не підозрюється у вчиненні насильницького злочину, навіть якщо незастосування смертоносної сили може призвести до втрати можливості заарештувати втікача[8].

Будь-яке встановлення цивільної або кримінальної відповідальності за порушення права на життя з боку держави має призвести до виплати компенсації найближчим родичам постраждалої особи незалежно від необхідності встановлення особи, яка несе кримінальну відповідальність за відповідне діяння.

Необхідно враховувати, що основні фрорми мирних зібрань необхідно виокремити в окремих нормах законодавства та розкрити їх характеристику для визначення особливостей процедури підготовки до проведення мирних зібрань залежно від мети та кількості осіб, задіяних до мирного зібрання. Слід брати до уваги, що в останні роки в Україні набувають популярності нові форми мирних зібрань (театралізовані виступи, флешмоби тощо), і не виключено, що нові фрорми будуть з'являтися і в подальшому. Саме тому вважаємо, що використання родового поняття «мирні зібрання» або ж «мирні збори» є доцільнішим, аніж перераховування у Конституції всіх можливих видів (форм) мирних зібрань. Враховуючи зазначене вище, пропонуємо внести зміни до статті 39 Конституції України[1].

У науковому, громадському і суддівському середовищі протягом останніх двадцяти років точаться дискусії щодо необхідності ухвалення спеціального закону (або ж законодавства) щодо організації мирних зібрань. Вартими уваги, на наш погляд, є дві точки зору: 1) закон про мирні зібрання $є$ необхідним у зв'язку із недостатністю національного законодавчого регулювання у цій сфрері; 2) жодного законодавчого регулювання цієї сфери у принципі непотрібно, є ст. 39 Конституції України, і її абсолютно достатньо для реалізації права на мирні зібрання.

На наш погляд, за умови наявності ідеальної судової практики, кваліфікованих дій працівників інших владних органів, насамперед правоохоронних, дійсно не було б великої необхідності у суттєвих законодавчих змінах. Але оскільки ситуація щодо забезпеченням права на мирні зібрання в Україні далека від ідеальної, такі зміни $\epsilon$ абсолютно необхідними.

Також дискусійним на сьогодні $€$ питання чи потрібен спеціальний закон про мирні зібрання, чи можна обійтися лише внесенням змін до чинного законодавства. Зазначимо, що у різних країнах питання необхідності існування спеціального закону про мирні зібрання вирішено по-різному. Та все ж таки переважна більшість держав, представлених у Раді Європи, такі закони мають.

Які ж саме зміни наразі вкрай необхідні у національному законодавстві? На наш погляд, наразі доцільним є закріплення принципів права на мирні зібрання. Зокрема, необхідно імплементувати принципи до Закону України «Про гарантії держави щодо виконання судових рішень», керуючись якими суди та органи виконавчої влади повноцінно та неупереджено будуть виносити рішення

Також, доцільно Міністерству внутрішніх справ України забезпечити обов'язкове регулярне оприлюднення офіційних статистичних та моніторингових даних про кількість мирних зборів та їх учасників. Створити окремий реєстр мирних зібрань, де буде накопичуватися інформація про заяви на проведення мирного зібрання, мети проведення, кількості учасників, що в подальшому полегшить судові розгляди у разі виникнення протиправних дій будь-якої із сторін.

Крім того, досить актуальною є впровадження норми про притягнення до адміністративної відповідальності, введення ст. 185-14 КУпАП «Підкуп громадян з метою залучення їх до участі у мирних зібраннях».

Продовжуючи аналіз, перейдемо до визначення позитивних обов'язків держави при проведенні мирних зібрань. Так, згідно з Керівними принципами ОБСЄ зі свободи мирних зібрань та прецедентною практикою Європейського суду з прав людини, у держави існують позитивні обов'язки щодо проведення мирних зібрань. Під позитивними обов'язками держави розуміють обов'язки сприяти проведенню мирного зібрання та захищати мирне зібрання. Кожен з цих обов'язків, на нашу думку, має бути закріплений не лише у якості принципу, але й детальніше розкриватися у конкретних законодавчих нормах. В Україні ж закон не містить переліку позитивних обов'язків держави або, інакше кажучи, послуг, якими держава або органи місцевого самоврядування забезпечують учасників мирних зібрань, що потенційно збільшує ризик невиконання державою своїх позитивних обов'язків.

Тому доцільно до Закону України «Про адміністративні послуги» внести зміни та виокремити одну з послуг - розгляд заяви на забезпечення охорони мирного зібрання. Таким чином, на рівні закону необхідно покласти на державу обов'язок здійснення охорони мирних зібрань, про які вона була повідомлена завчасно. Найбільш очевидним обов'язком держави з охорони мирного зібрання $є$ забезпечення присутності на ньому достатньої кількості правоохоронців, а також 
здійснення заходів щодо розмежування учасників контр-демонстрацій за наявності такої потреби. Конкретна ж кількість правоохоронців має визначатися з урахуванням прогнозованої кількості учасників зібрання, гостроти його тематики та локації, на якій планується його проводити.

Вищенаведене не слід сприймати таким чином, ніби відсутність завчасного повідомлення зовсім знімає з держави обов'язок охороняти мирні зібрання. Однак держава не може нести відповідальності за зрив такого мирного зібрання 3 будь-яких підстав (наприклад, через дії контр-демонстрантів), якщо тільки фактичне зволікання правоохоронних органів не було занадто тривалим і умисним.

Обов'язок держави сприяти проведенню мирних зібрань, на наш погляд, має полягати не тільки у невтручанні, але й у вчиненні певних позитивних дій. Так, держава в особі органів поліції має взяти на себе обов'язок проведення заходів з медіації у випадку, якщо кілька організацій мають намір провести непов'язані між собою мирні зібрання в одному й тому самому місці, в один і той же час (одночасні мирні зібрання), або у випадку наміру одночасного проведення контр-зібрань. Обов'язок медіації доцільно закріпити на законодавчому рівні (Закон України «Про медіацію мирних зібрань») або ж на підзаконному рівні.

Наступним шляхом удосконалення $€$ визначення строків, форми та порядку завчасного сповіщення про мирні зібрання. Спільним наказом МBC, органами місцевого самоврядування «Про порядок взаємодії уповноважених суб'єктів щодо забезпечення публічного порядку під час проведення різних форм мирних зібрань» та іншими уповноваженими особами, де перебачити строк завчасного сповіщення не менше 72 годин з моменту погодження заяви про проведення мирного зібрання з органами місцевого самоврядування.

У наказі необхідно визначити форми мирних зібрань, окремі процедури охорони публічного порядку залежно від кількості учасників мирного зібрання, можливості залучення відповідних уповноважених осіб, де прописати спрощену процедуру залучення інших правоохоронних органів до забезпечення публічного порядку (Національну гвардію, Збройні сили та інші військові формування).

Наступним етапом удосконалення $€$ доцільність зобов'язати органи державної влади та органи місцевого самоврядування використовувати практику Європейського суду з прав людини як джерело права. Стаття 19 Закону України «Про виконання рішень та застосування практики Європейського суду з прав людини» зобов'язує національні суди використовувати Конвенцію та практику Європейського суду як джерело права в діяльності органів виконавчої влади, органів Національної поліції та Національної гвардії.

Потрібно розмежувати мирні зібрання та інші масові заходи. Наразі на законодавчому рівні в Україні мирні зібрання та інші масові заходи спортивного, розважального чи культурно-просвітницького характеру не розмежовані. Більше того, як свідчить державна статистика таких заходів, влада розглядає їх як заходи одного типу. Подібний висновок можна зробити і з огляду на існування актів органів місцевої влади, які визначають порядок проведення недержавних масових заходів.

Окрім окреслених напрямів удосконалення законодавчого регулювання деякі проблеми потребують подальшого обговорення, зокрема, за участі науковців, з метою знаходження оптимального способу їх вирішення. До таких питань, на нашу думку, передусім належить питання вирішення колізій між правом на мирні зібрання та правом власності, яке виникає під час спроби проведення мирних зібрань на території, що має певного власника, а також проблема зловживання правом на мирні зібрання з боку учасників протесту (зокрема, шляхом блокування публічних доріг).

Висновки. Такий стан речей у вітчизняному законодавстві порушує принцип правової визначеності, відкриває широке поле для зловживань, і не дає змогу громадянам з достатнім ступенем вірогідності передбачити наслідки своєї поведінки, правомірної чи протиправної. Недоліки у нормативному регулюванні за певних обставин могли б бути виправлені за допомогою хорошої практики правозастосування. Однак за результатами нашого дослідження ми виявили значні недоліки у судовій практиці щодо реалізації права на мирні зібрання. Зокрема, судова практика щодо обмеження мирних зібрань $€$ не уніфікованою та погано вмотивованою, для неї характерні тенденції щодо розширювального тлумачення підстав для обмеження мирних зібрань та недостатнє використання принципу пропорційності під час балансування інтересів учасників мирних зібрань та інших громадян. Крім того, наявні узагальнення української судової практики щодо цієї сфери також виявилися нездатними вирішити наявні проблеми правозастосування.

Одним з можливих виходів є потреба ширшого використання практики Європейського суду 3 прав людини, яка дає змогу відповісти на більшість питань, що виникають у питаннях забезпечення права на мирні зібрання. 


\section{БІБЛІОГРАФІЧНИЙ СПИСОК:}

1. Конституція України : прийнята на п'ятій сесії Верховної Ради України 28 червня 1996 р. Верховна Рада України. Відомості Верховної Ради України. 1996. № 30. Ст. 141.

2. Кобрусєва Є.А. Судовий розгляд справ у провадженнях щодо мирних зібрань. Правова позиція. 2020. №4 (29). URL: http://chernvisn.nuoua.od.ua/index.php/avtoram.

3. Засоби правового забезпечення прав і свобод людини. Київ, 2014. URL: https: www.naiau.kiev.ua/files/ kafedru/kmp/lectures/pslg/lekc3-pr-svob.doc.

4. Конвенція про захист прав людини і основоположних свобод від 04.11.1950р. Голос України. 10 січня 2001 рік. № 3. URL: https://minjust.gov.ua/m/konventsiya-pro-zahist-prav-lyudini-i-osnovopolojnih-svobod-taevropeyskiysud-z-prav-lyudini.

5. Йосифович Д.І., Андрусишин Р.М. Проблеми реформування органів виконавчої влади. Науковий вісник Львівського державного університету внутрішніх справ. 2018. № 4. С. 150.

6. Справа «Ідентоба та інші проти Грузії» (заява № 73235/12, пункти 75-78 від 12.05.2015). URL: https://courses. ed-era.com/assets/courseware/9e466733eab9aeb296f9e4ce7973e27c/asset-v1:EdEra+HR201+hr201+type@ asset+block/1P1

7. Справа «Ізджи проти Туреччини» (İzci v. Turkey) від 23 липня 2013 року. Єдиний державний реєстр судових рішень. URL: http://eurocourt.in.ua/Article.asp?Aldx=607.

8. Nachova v. Bulgaria (Начова против Болгарии): решение Первой Секции. URL: https://www.srji.org/ resources/search/21.

9. Загальна декларація прав людини. URL: http://zakon2.rada.gov.ua/laws/show/995_015

10. Міжнародний пакт про громадянські і політичні права. URL: http://zakon1.rada.gov.ua/laws/show/995_043

11. Свобода мирних зібрань у практиці Європейського Суду з прав людини. URL: http://pravo.org.ua/files/_ murni_zibranya.PDF.

\section{REFERENCES}

1. Konstytutsiia Ukrainy : pryiniata na piatii sesii Verkhovnoi Rady Ukrainy 28 chervnia 1996. Verkhovna Rada Ukrainy. Vidomosti Verkhovnoi Rady Ukrainy. 1996. № 30. art. 141.

2. Kobruseva, E. A. (2020). Sudovyi rozghliad sprav u provadzhenniakh shchodo myrnykh zibran [Judicial review of cases in proceedings concerning peaceful assemblies] Pravova pozytsiia. 4 (29). URL: http://chernvisn.nuoua. od.ua/index.php/autoram. (in Ukrainian).

3. Zasoby pravovoho zabezpechennia prav i svobod liudyny. Kyiv, 2014. URL: https: www.naiau.kiev.ua/files/ kafedru/kmp/lectures/pslg/lekc3-pr-svob.doc. (in Ukrainian).

4. Convention for the Protection of Human Rights and Fundamental Freedoms of November 4, 1950. Voice of Ukraine. January 10, 2001 № 3. URL: https://minjust.gov.ua/m/konventsiya-pro-zahist-prav-lyudini-i-osnovopolojnihsvobodta-evropeyskiy-sud-z-prav-lyudini. (in Ukrainian).

5. Yosifovich, D.I. \& Andrusishin, R. M. (2018). Problemy reformuvannia orhaniv vykonavchoi vlady [Problems of reforming the executive branch]. Naukovyi visnyk Lvivskoho derzhavnoho universytetu vnutrishnikh sprav. no. 4. 150. (in Ukrainian).

6. Sprava «Identoba ta inshi proty Hruzii» [Case "Identoba and Others v. Georgia"] (application no. 73235/12, §§ 75-78 of 12 May 2015). URL: https: //courses.ed-era.com/assets/courseware/9e466733eab9aeb296f9e4ce7973e2 7c/asset-v1: EdEra + HR201 + hr201 + type @ asset + block / 1P1.

7. Sprava «lzdzhy proty Turechchyny»[The case of İzci v. Turkey] of 23 July 2013. Unified state register of court decisions. URL: http://eurocourt.in.ua/Article.asp?Aldx=607.

8. Nachova v. Bulgaria (Nachova v. Bulgaria): decision of the First Section. URL: https://www.srji.org/resources/ search/21.

9. Universal Declaration of Human Rights URL: http://zakon2.rada.gov.ua/laws/show/995_015 (in Ukrainian).

10. International Covenant on Civil and Political Rights URL: http://zakon1.rada.gov.ua/laws/show/995_043 (in Ukrainian).

11. Freedom of peaceful assembly in the practice of the European Court of Human Rights URL: http://pravo.org. ua/files/_murni_zibranya.PDF (in Ukrainian). 